\title{
Equitable multilingualism? The case of Stellenbosch University Writing Laboratory
}

\author{
Sharifa Daniels \\ Language Centre, Stellenbosch University, South Africa \\ E-mail: sdaniels@sun.ac.za
}

\author{
Rose Richards \\ Language Centre, Stellenbosch University, South Africa \\ E-mail: rr2@sun.ac.za
}

\begin{abstract}
This article reflects on Stellenbosch University Writing Lab's pedagogical approach to multilingualism and inclusivity within the complex and political nature of multilingual language policies at a South African university. The Writing Lab has always been promoted as a facility for all students, not just those in need of 'remedial' support. This was a departure from earlier academic literacies models that tended to view students from nondominant language groups in terms of deficits. Academic literacies research has pointed to the shortcomings of these earlier approaches and to the value conflicts that arise from them. We, in contrast, argue that Carter's (2009) writing centre paradox provides a dynamic rhetorical space in which to explore issues around South African multilingualism and inclusivity in higher education, and for this reason we do not wish to resolve the paradox. Instead, we use it to critically appraise our type of equitable multilingualism and maintain and honour multivocality. We also argue that South African writing centres enjoy a somewhat different trajectory from that of many other academic literacies spaces by virtue of the one-to-one pedagogy and mutualistic approach we follow at these writing centres. This has allowed us simultaneously more agency and less agency and we need to use this paradoxical position strategically in our institutions. Using the Writing Lab as a case study, we reflect on the ways in which the Writing Lab gives life to its ethos of being a multilingual and inclusive space for academic transformation within the institution's language policy. To support our reflections, we draw on descriptions of the organisational structure of the Lab, feedback received from strategic role players and observations of interactions performed in the various Lab spaces. We also consider the Writing Lab in terms of South African writing centre scholarship to see how the Lab's philosophy and ethos compare with the ideals.
\end{abstract}

Keywords: academic literacy, multilingualism, transformation, writing centre paradox, writing centres 


\section{Introduction}

Emerging from the context of apartheid education, many South African higher education writing centres began as skills centres for previously disadvantaged students. Often established as projects, the main aim of these writing centres was to support these students by developing their academic writing practices and in this way to help smooth the transition to higher education (Archer and Richards 2011). While the original aims were idealistic, honourable and transformative, one could argue that this was a 'deficit' approach because it targeted a specified group of students only. These writing centres were often labelled as "remedial" or "handmaidens of the institution" (Grimm 1996a:524) and were literally and figuratively situated in peripheral places. A serious omission in this way of thinking about academic literacies was the lack of acknowledgement of the dynamic linguistic higher education landscape. The Writing Lab at Stellenbosch University (SU) that Leon de Stadler started was a departure from existing South African models in that the Writing Lab began as a multilingual and inclusive space within higher education. De Stadler envisioned and planned a space where both the languages of teaching and learning at the time, Afrikaans and English, could enjoy equal status and where conversations about writing could thrive in a nonthreatening environment. This new space would not only allow students to learn to write academically but it would also foster what De Stadler described as writing to learn rather than learning to write (Language Centre 2004). The new Writing Lab would also be visible evidence of the University's intention to adopt more student-centred pedagogies and to position itself as "a language-friendly university, with a responsive and flexible approach to language of instruction" (SU 2000:19).

In the time that the Writing Lab has existed, we have witnessed the University's language policy adapting to the changing social and political situation in the country and on campus. We have experienced the social changes in specific ways because of our individual contact with writers. Because of this, we have long been wrestling with the ideas of language equity and language equality. Though the Writing Lab was started in response to a need for academic writing development on campus, it has always been promoted as a facility for all students, not just those in need of 'remedial' support. The Writing Lab ethos was to acknowledge and reflect the multilingual nature of South African students in higher education by formally having a degree of language 'equality' in its structure and practice. Nonetheless, we find ourselves in an intriguing nexus of conflicting and sometimes competing values. For instance, we exist to help students develop their academic writing. But what does this mean and what are its implications? Boughey (2010) and Thesen (2013) allude to the complicity inherent in a practice that inducts students into university as if the writers come with nothing of their own and no prior expertise. How do we negotiate this? Given the complex and political nature of multilingual language policies at South African universities, we were interested in how theory could translate into practice in a writing centre.

We have selected three key experiences from the early years of our existence that influenced some of our thinking on the issues of multilingualism and inclusiveness and thereby shaped our theoretical approach moving forward. These experiences contain many voices. The first experience is the earliest one. One of our first students taught us much about inclusion in a multilingual environment. The second experience concerns a turning point in a writing consultant's professional development, told partly in her own words. The third shows the consultants' feedback about language use in the Writing Lab. To support our reflections, we draw on descriptions of the organisational structure of the Lab, feedback received from strategic 
role players such as consultants and students, and observations of interactions performed in the various Lab spaces.

To shape our discussion, we ask the following questions: How is multilingualism practised in the Writing Lab in different contexts? How do we consider inclusivity in our environment? How does language usage in the Writing Lab respond to or reflect the language policy of SU? To what extent do we collude with a system that undervalues certain parts of its student demographic, and to what extent (if any) can we escape from colluding? We also draw on some of our findings from a chapter in the book Changing Spaces (Daniels and Richards 2011) in which we consider equity ${ }^{1}$ or equality ${ }^{2}$ in the Writing Lab.

\section{Academic literacies and the writing centre paradox}

For the purposes of this article, we have drawn on a particular body of writing centre work that problematises multilingualism and inclusivity. We have also drawn on South African and international academic literacies research. We have found that while our experiences in the Writing Lab have mirrored some of those described in the literature, our unique placement as a writing lab in an officially multilingual university provides us with many daily opportunities to reflect upon, to engage with and to renegotiate these issues.

South African writing centres of the 1980s and 1990s developed as a response to the changing student demographic in formerly white liberal universities at the demise of apartheid (Boughey 2010). Writing centres, as other academic support interventions of that time, were positioned as remedial support for "disadvantaged" or "underprepared" black students (Boughey 2010:89). This origin is problematic in different ways. Firstly, black students are seen in terms of deficit, and, secondly, they are seen as being in need of adapting to the institution. The legacy of this pernicious deficit narrative survives in higher education today and affects how many students are received at university.

By the time the SU Writing Lab was conceptualised in 2001, arguments for an academic literacies approach to student writing (Archer 2010) were gaining momentum in South Africa. According to this ideological model of literacy, literacy was "understood as multiple, socially situated and contested" and literacy learning involved "learning particular roles, forms of interaction and ways of thinking" (Archer 2010:497; see also Gee 1990; Lea and Street 1998; Boughey 2010; Clarence 2012; Clarence and McKenna 2017). Academic literacies in particular, it was argued, had an epistemology of "literacy as social practice" and a transformative ideology (Lillis and Scott 2007:14).

This understanding of academic literacies had a strong impact on the discourse around academic literacies development and support in South Africa, including the work of writing centres. Because South African writing centres were initially established to develop the academic writing of historically disadvantaged students and were mostly located outside academic departments, concerns were raised about their roles and impact. Some of the criticisms were that writing centres were perpetuating the status quo, were nontransformational and served as 'handmaidens' to higher education institutions (Grimm 1996a; Clarence and McKenna 2017).

1 By equity we refer to the quality of being fair in our treatment of language. This could mean using a language that all students understand, even if it is no one's first language.

2 By equality we mean treating languages equally. This could entail ensuring that each language enjoys the same amount of representation in the Writing Lab. 
According to this discourse, writing centres were providing writing support that was 'autonomous' and writing centres tended to teach writers 'isolated skills'. Another concern was that "different approaches to student writing" could also impact on the "character and identity of a Writing Centre within the educational system" (Archer 2010:497).

These concerns about the "regulatory role" (Grimm 1996b:5) of the writing centre and how we positioned ourselves as a writing centre are matters that the Writing Lab has acknowledged and constantly taken cognisance of over the 16 years of our existence and that we considered in building our identity and developing our praxis. Grimm argues that placing our work within an "ideological model of literacy and an articulatory model of social change" (1996b:6) could be beneficial. She proposes that "[i]nstead of theorizing writing centers as sites of individualized instruction, we need to theorize writing centers as places where mutual transformations occur" (1996b:17).

But what power do we have to do this? After all, we are part of the institution and, as Gillam (1991:5) asserts, the writing centre acts as "normalizing agent and liberating agent simultaneously". We help writers to find their voice, but we train those voices to speak a certain way so that the writers can succeed academically (Carter 2009).

Because of this, Carter (2009:136) maintains that writing centres experience what she calls the "writing center paradox":

The writing center is made up of a series of rhetorical spaces in which tutors and students attempt to negotiate academic projects assigned by and evaluated by individuals who are not directly associated with/involved in the writing center's daily activities. We represent the student, not the teacher. We represent the system, not the student. We represent neither, and we represent both.

Moreover, Mahala (2007:4) describes "how emerging pressures in the managed university can complicate ... some of the core values of writing centers". One such pressure is the sheer number of students. Another is the increasingly heterogeneous backgrounds of the students. These complicate writing centre values because they can pressure writing centres into providing a set of technical skills at the expense of the other transformational and access-related benefits that writing centres can provide. This feeds into Badat's (2010) description of value conflict in academic literacies.

Central to this is our pedagogy. Writing centre work adopts a pedagogy underpinned by peer and collaborative learning. Nichols (2014:896) describes South African writing centre pedagogy as coming from the United States of America and from "ideas of dialogue producing new knowledge and avoiding the premature closure of meaning". She further explains, "As an idea it is at odds with political legacies of controlling who speaks, who listens, and who is noticed." This is immensely powerful in South Africa where historically so many voices have been silenced.

As much as writing centres have been and often still are positioned as support or development services, their trajectory has been somewhat different from that of the rest of academic support services. This may be a result of our "liminal freedom to work with many constituencies", and, as such, we can facilitate different types and levels of change (Nichols 2014:905). One of our great strengths is the one-to-one way in which we work with writers. Our method is premised 
on adapting to the individual's needs and not relying on what we assume the individual requires. Writing consultations also depend heavily on engaging with writers and developing writing relationships with them. Carter (2009:136) describes our position as follows: "[I]t seems the writing center worker is uniquely situated for investigating the power nexus involved in acquiring new literacies." The power imbalance at South African universities became a cause of national concern in 2015 and 2016 with the \#feesmustfall movement. However, SU was already experiencing student-led protest in 2014. This student-led protest movement at Stellenbosch culminated in the release of a YouTube video, Luister (Listen), ${ }^{3}$ in which students shared their experiences of racism at the University (Contraband Cape Town 2015). It was clear that no one had been listening to them for a very long time. For real transformation to occur on university campuses, listening to dissonant and othered voices is essential (Nichols 2014).

The video made for painful listening and drove home a hard point about whose voices were heard and whose perspectives mattered on campus. This fed into the subsequent \#feesmustfall movement. Boughey and McKenna (2016:2) show that these student-led movements and academic literacies are very much concerned with "the mastery of a "way of being' required of students as they engage with higher education" and with how a preoccupation with language deficit allows "social differences and institutional culture issues to be erased under the label of a supposedly neutral 'language problem' inherent in the student". At the Writing Lab, we have always been careful to move away from such deficit models and to take a more holistic approach to students to help them master the ways of being required of them.

\section{The Writing Lab's inclusive paradigm}

The Writing Lab subscribes to the view that inclusion is a basic human right (Daniels and Daniels 2017). For us, inclusion is much more than just giving students access to the University. It also involves supporting and enabling students to participate in academic discourse and to gain acceptance at the institution. Following an inclusive approach further involves "increasing participation for students" and also "removing the barriers that [help] to exclude them" (Daniels and Daniels 2017:307). In the Writing Lab's Aims and Services (Language Centre 2004:1) document, we declare that we want to

create an environment in which all students and lecturers of Stellenbosch University, no matter what their status, their level of experience, or their discipline, can enter into and participate in scientific discourse through their writing [italics added].

This approach has also influenced the choices that we have made in terms of our pedagogy. One of the primary characteristics of inclusive education is supporting and embracing flexible pedagogies. Our engagement with language in consultations shows that we adapt to the needs of the writer and that consultants are flexible in how they use language to communicate with students. Instead of insisting on rigid and formal language use when interacting with students, consultants are creative and are not averse to embracing the linguistic resources that students bring to the consultation conference. An example of this would be to speak informally and to use code switching (changing register and changing languages) during consultations. This way

Luister focuses on the experiences of students of colour at SU. The documentary examines the prejudice that the students experience at university and in the university town itself. It also considers Afrikaans as language and culture and the ways in which this acts as a barrier to the institution. Students speak different types of Afrikaans, but only one type is valued. See https://www.youtube.com/watch?v=sF3rTBQTQk4. 
of using language has proved to be more inclusive and also to be an acknowledgement that the student comes with resources that could enhance learning (Daniels and Richards 2011).

In inclusive education, collaboration is an important strategy. Among the defining characteristics of collaboration that Swart and Pettipher (2005:19) identify are that collaboration is "voluntary", "requires parity among participants", is "based on mutual goals", "depends on shared responsibility for participation" and entails "sharing accountability for outcomes". These are all elements that underpin and are present in a typical writing centre consultation (Harris 1986; Gillespie and Lerner 2008).

One of the qualities that draw writers to the Writing Lab is that it teaches them how to write better and thereby achieve better marks. Our consultant training is partly about that, but it is also about other aspects of communication and meaning making. In our consultant selection process and in our consultant training, we emphasise active listening as a powerful consulting technique:

In the one-to-one consultations, the consultant has to listen actively to the client's writing and thinking and help him or her to surface tacit knowledge and build upon it, and then communicate in his or her particular writing situation effectively. The one-toone consultation is a replicable activity which once experienced can be reproduced by the client.

(Nichols 2014:901)

Nichols (2014:899-900) goes as far as describing "the importance of promoting active listening" as writing centres" "best contribution to transformation" and that "interrelationships become generators of meaning and change". Therefore, what we say, what language we speak but also how we listen are key elements in why writing centres can contribute to transformation (Nichols 2014).

\section{Multilingualism: Language equity and equality?}

Around the time that the Writing Lab was established, the Language Policy for Higher Education (RSA 2002) challenged higher education institutions to develop multilingual environments while at the same time ensuring that languages of teaching and learning would never be a "barrier to access and success" (RSA 2002:4). The result was that higher education institutions developed language policies that advocated for multilingualism in a more multicultural context. Often these policies were theoretically sound but their implementation proved to be challenging (Cele 2004). In reflecting on the language policy at his university (where English is the academic language) Madiba (2012) admits that "although [the language policy] opens up agentive and implementation spaces for multilingualism in the classroom, [it] falls short of transforming ... the historically entrenched ... monolingual ideology in the university". He encourages the university to "critically rethink its traditional approach to language use in class". In this way then "new multilingual pedagogies that promote inclusivity and active participation of all students in the learning process" could be created. He cautions that if attention is not paid to language use in classrooms (or spaces such as writing centres), "the goals of transformation could be promoted or undermined" (Madiba 2012).

This dilemma seems to have been the case at SU also in terms of the interpretation and implementation of language policies and plans. When we were appointed as heads of the 
Writing Lab, we were appointed partly on the basis of language. Having an Afrikaans head and an English head was a strategic move to represent symbolically and pragmatically that in the Lab, the University's two languages of teaching and learning enjoyed a degree of equality. This was a response to the heated debates on campus about the status of the two academic languages. From the beginning, as part of "honoring the multivocality" (Geller et al. 2007:97 in Ronesi 2009:80) of campus, we have ensured that we appoint consultants who can speak either or both academic languages and that the writers can choose which language they prefer to consult in. This is a departure from what often happens in most South African writing centres.

However, having two heads, each representing a language, or an equal number of Afrikaans and English writing consultants does not necessarily guarantee language equality or language equity. Because we work across campus (Language Centre 2004), the needs of our writers dictate the language that we work in. Most of our students are second-language English speakers. The Afrikaans speakers have the opportunity to write in Afrikaans in most subjects, but those who do not speak Afrikaans or English as a first language (for instance, isiXhosaspeaking students ${ }^{4}$ ) are not writing in their first languages.

In her description of the trajectory of academic literacies in South African higher education institutions, Boughey (2010:6) purports that

[i]n the area of language development, the problems students experienced with reading and writing were usually understood in relation to their status as speakers of English as an additional language rather than in relation to theory which takes into account literacy as a socially embedded phenomenon.

Approaching language development in a context of social embeddedness has the "potential to provide richer and more satisfactory analyses of all aspects of students' experiences" (Boughey 2010:6). The form that this social embeddedness should take may be assumed to be institutionally created, but we maintain that the individual's social embeddedness is key to lasting transformation, inclusivity and multilingualism. This social embeddedness is formed by personal relationships and 'smaller' day-to-day activities, as we will show.

While the Writing Lab cannot change the institutional decision to have only two academic languages, we can provide a space for students to express themselves in the language of their choice academically. In consultation, students are welcome to speak in a language other than the University's two official teaching and learning languages if they prefer and if we can match them with a consultant who is also conversant in that language. We have found that this allows students to express themselves more freely. It also has the political dimension of allowing students to draw on resources with which they come to university and on identities that they already have. Our intention with this is that the students can practise mastering a way of being here.

In our chapter in the book Changing Spaces (Daniels and Richards 2011), we describe the SU Writing Lab as a contact zone (Pratt 1991) - a social space where different languages and cultures intersect. This intersection and clash happens against a backdrop of a language policy that is historically and politically charged and where issues of power relations play out. For this

4 The regional languages of the Western Cape are Afrikaans, isiXhosa and English. At SU, however, only a small percentage of the students are isiXhosa speaking. 
reason, we align ourselves with Alexander (2004:113) who asserts that a language policy is not a "decontextualized set of protocols" and that "all language planning, even that which denies that it is language planning, serves specific ideological and political ends".

In her study of the SU Writing Lab, Nicole Bailey (2016) contends that a multilingual centre needs to be based on a strong and fluid language policy for the whole institution. She found the Writing Lab to be a pivotal space for the language policy to thrive by including more languages than are specified in the policy. Her observations and interviews with our consultants show that, like Ronesi's (2009) multilingual consultants, they are using far more than just the two languages of teaching and learning at the institution. Bailey claims that we are in the ideal position to see how student language is changing before anyone else, and in that way help shape the policy as it evolves.

\section{Three key experiences in the Writing Lab: Working with multilingual writers}

To show how the issues of multilingualism and inclusivity often play out in our writing lab, we refer to three experiences of working with multilingual writers and consultants. These experiences also illustrate how theories about 'literacy as social practice' and having a transformative ${ }^{5}$ ideology translate into writing centre practice.

The first two experiences depict how traditional assumptions can influence the outcomes of consultations and the challenges that emerge from each of these experiences. In particular, we discuss our response to the experiences within the context of multilingualism, inclusivity and the 'writing centre paradox'. The third experience shows how multilingual consultants negotiate language use in their training and how dynamic the multilingual landscape can be at SU. What all these experiences have in common is that they are mutually transformative for all the various role players.

\subsection{Waiting at the door: The writer who felt like an outsider}

The importance and impact of our student-centred philosophy whereby all writers and their texts are treated with the utmost respect are shown in the following student's experience. Mandla, ${ }^{6}$ a first-language isiXhosa speaker, was writing in English at our predominantly Afrikaans university. He was referred to the Writing Lab by his lecturer who described his writing as poor. When he came for his first consultation, he was uninvolved and defensive. He kept a distance between him and us by hovering in the doorway until encouraged to enter the room and, on being invited to take a seat, by leaning far back in his chair, with his hat pulled over his eyes. He did not bring any writing with him; in fact, although the date for submission was drawing near, he had not started writing his assignment yet.

From our conversations with him, we discovered that he regarded his visit to the Writing Lab as punishment because he thought that he was being singled out as a student whose writing was below the level of the rest of the class. As we started talking to him about his attitude to writing in general, it emerged that he did not like writing. In fact, he was afraid to write because he

\footnotetext{
5 We subscribe to the same view of transformative pedagogy as Farren (2016:191) does: the participants are "whole people at the centre of the educational project", and we create conditions that support them in developing their relationship to each other and to build autonomous learning. It makes "connections between teaching and learning, and living" (2016:192).

6 Mandla is a pseudonym.
} 
made many grammar and spelling mistakes and did not have the English academic vocabulary to express his ideas. This made him feel stupid. It also emerged that he kept quiet in class because he was the only new student and the only black student in the class. He saw himself as representative of his former historically black university and did not want that institution to be judged negatively because of his performance in class.

Mandla was encouraged to come for a series of consultations, and it was remarkable how his confidence grew with each consultation. We discovered that he could speak engagingly and with insight about his field of study and the topic of his assignment. Together with him, we worked out ways in which he could transfer his ideas to paper. These included breaking down his assignment into small, manageable parts and redrafting his document a number of times, looking at different foci in each draft (coherence, paragraph structure and, only at the end of the process, grammar and spelling).

One day he visited the Writing Lab to thank us for the help that we had given him with his writing. He said that he felt so empowered that he felt he "could now write a book". What had especially motivated him after his visits to the Writing Lab was the encouragement that he received there and the way in which his smallest and humblest writing attempts were praised and respected. By coincidence, with his permission, we had decided to use the different drafts of his paper as material for discussion in our next consultant training session. The drafts were far from perfect or what writing experts would rate as 'good', but the progress in each draft could clearly be seen. On the spur of the moment, we asked him whether he would like to attend our next training session to tell the consultants about his experience of his consultations at the Writing Lab.

Before the training session, a few of the consultants were discussing the drafts in a light-hearted (and judgemental) manner, not knowing that the writer was in their midst. Then Mandla was given the opportunity to address the group of consultants. As he talked about his visits to the Writing Lab and how empowering the experience had been for him on more than one level, it started dawning on the consultants that this was the writer of the drafts to be discussed.

Through Mandla's describing his changing relationship with writing, the consultants gained insight into the reality of the student and how the consultation sessions had contributed to his development as both writer and student. Had his drafts been used for an exercise in error analysis, they probably would have been 'torn to shreds', but now, for the first time, the new consultants became aware of 'the person behind the text'. They could clearly hear that this was a very intelligent student whose texts did not reflect his potential. They also realised why being nonjudgmental is such an essential principle within our writing lab's philosophy. Students like Mandla, through their difficulty with communicating effectively in academic English writing, often continue to function on the periphery of the academic community at South African universities.

\subsection{Seeing the light: Challenging, changing and transforming consultant assumptions}

Many second-language speakers' skills in writing in their second language lag behind their speaking abilities, even at university level. Their academic backgrounds, which are often very different from those of 'successful' tertiary students, may not be taken into account. This can lead to their being seen as less academically able than the other students and less academically able than they in fact are. Traditional assumptions such as these are often challenged at the 
Writing Lab. When working individually with students, it is difficult to keep one's preconceptions unchanged, as the following instance shows.

Emma, ${ }^{7}$ a new consultant, was a first-language speaker of English. She had a private school background and was highly successful academically in her school and undergraduate studies. Her academic background was in literature, and she was an excellent writer. In one of her first consultations at the Writing Lab in 2004, Emma was required to work with a student whose academic background differed vastly from her own. In high school, the student's language of learning was Afrikaans with English as an additional language. Now as a first-year student in the social sciences, he was enrolled for English 178, a compulsory module for all students in that faculty whose language of teaching and learning in high school was not English.

After her first consultation with the student, Emma expressed strong views about the student's proficiency in English and his academic ability to succeed in higher education. She raised concerns about whether this student should have been allowed to study at the University in the first place. By coincidence, I (one of the authors) had consulted with the same student the previous day and my experience differed vastly from Emma's. Although the student was a second-language speaker of English, he was eager to participate in the consultation. This was a first consultation in which we did an analysis of the assignment and brainstormed ideas. While he was producing all these ideas, I listed them. The student was surprised at himself and the amount of ideas that he was generating. In fact, he became so excited about his progress that he subsequently asked whether we could end the consultation before the allotted time so that he could now develop the ideas that he had generated. He left the consultation energised, extremely happy and highly satisfied with his own performance.

Emma's consultation was therefore a follow-up consultation in which they would continue on the work done in the previous consultation. Although the second consultation can often be a bit more challenging as students now have to develop their initial brainstormed ideas and produce a more coherent piece of writing, I was still puzzled about Emma's (hasty) conclusion. I saw this as an opportunity to explain to her how our writing centre theory translated into practice. I could also set her mind at rest that she should not be too hard on herself and have unrealistic expectations about the outcome of a single consultation. But more particularly (as a former principal of a high school similar to the one that the student had attended), I could provide her with more context about the differing educational backgrounds and routes via which South African students accessed university. At the student's school, where all learners from primary schools in this socioeconomic neighbourhood were automatically accepted, classes included a diverse range of learners - from those academically strong to those who struggled to keep up. In such a context, the focus of the teacher was typically on ensuring that most learners passed the year-end exams. Thus individual attention to academically stronger learners was mostly not possible, the reasoning being that they could get on by themselves. When such learners arrived at university, they needed time to adapt and make the transition to higher education. This is where writing centres could be crucial to the academic acculturation of students.

When I sketched to Emma the student's possible school experience, she was shocked. As someone from a totally different schooling background, she did not imagine the chasm that existed between different learners' schooling experiences and their trajectory to university. She further wondered whether her hasty assumptions about the academic ability of the student might

$7 \quad$ Emma is a pseudonym. 
have been presumptuous and realised that in order for her to grow as a consultant, it was important to reflect on her experiences. The following report was subsequently submitted by Emma:

During my first week of consulting I came into contact with a first year English student who caused me not only to doubt my own abilities as a teacher, but also, perhaps more importantly, to question the ability of secondary and tertiary education systems to provide adequate support for students needing academic assistance. This student's first language is not English, his mother tongue being - as far as I know - Xhosa. Preferring to consult in Afrikaans, this meant that the student was writing in his third language.

Emma's preconceptions, shared by many educationists, concerning what she could expect from such a student were challenged when consulting with him. However, her new opinion of the student's abilities was met by a new challenge:

I was, thus, pleasantly surprised at the standard of the student's written English; it was at times faulty and colloquial, but it was - generally - clear, precise and expressive. It was this discrepancy between the student's language and essay writing skills that completely skewed the manner in which I helped him - I assumed that he knew and understood far more than he really did.

After a frustrating third consultation, Emma came to the following realisation:

[O]ur student's progress - which was not as much as I had hoped for or believed him capable of - must have been, for him, an enormous leap forward in thinking about writing. I forget how alien a basic structure for an essay must seem for someone who has never written an academic essay before.

Emma started to see that students such as the one whom she worked with came from academic backgrounds very different from her own. She appreciated how he had struggled to write a seemingly straightforward assignment because the course that he was taking made little provision for students whose secondary academic experiences did not conform to the 'norm' (in fact a privileged minority). Instead of locating the problem in the student, Emma started to realise that the system needed to change and be challenged. Her newfound knowledge served to perplex and disillusion her but also to empower her as a consultant:

[A]bove all, I feel angry. Knowing how much effort the student has taken to write this rather simple essay, I wish I could warn him that he will not receive a very good mark for it. How is it that the university can allow this student - who has, I think, academic potential - to struggle alone? ... I feel I am able to make some small contribution in this regard as a consultant for the Laboratory, but this does not diminish my sense of outrage at the education system's failure to properly educate this student.

\subsection{Consultant training in the third space: Language equity or language equality in a multilingual environment?}

The third experience concerns how the ideology of our organisational structure and the lived reality of the Writing Lab influence each other. Our environment is designed to be as inclusive as possible in a multilingual environment. By this we refer primarily to the way in which we 
consult with students. A type of inclusion that is often overlooked, however, in writing centre research is the way in which consultants relate to each other. Devet (2011:6) refers to writing consultants as the writing centre's "forgotten clients". Consultants, like teaching assistants, occupy a third space between student and lecturer, and their needs overlap with those of both these categories (Guttiérez 2008). In addition, the way in which they interact with each other is one of the ways in which the Writing Lab's ideology and ethos play out. In this section, we discuss how the consultants negotiate language use in consultant training.

Language has always been one of the considerations when we recruit postgraduates as writing consultants. Not only do we appoint postgraduate students from across disciplines, but we are also keen to find out which languages they feel confident consulting in about academic work at SU. In our advertisement, we invite students who have good mastery of either Afrikaans or English to apply for a position as a writing consultant. We find that many of the applicants are at least bilingual but that they tend to select an 'academic language'. This would be the language in which they conduct most of their own academic writing and the language in which they feel more confident consulting.

Language equality in consultant training has not been as straightforward as it may at first have appeared. We have found since our first intake of consultants that the great majority of our consultants are not first-language English speakers and that many are not able to speak Afrikaans. Because of this, our consultant training (which runs throughout the year) takes place in English, with a small amount of code switching into Afrikaans. This use of language has always deviated from the 2002 Language Plan that set requirements for whichever language option an academic environment selected to implement. ${ }^{8}$ In the Writing Lab, we have been able to be more creative and flexible in terms of language use because we work individually with students. Here we shuttle between discourses, especially in the case of Afrikaans students writing in English. To be more inclusive, we adapt how we use language to suit the learning mode of the student. This more flexible and creative use of language has proved to work in our favour within this dynamic linguistic landscape that has seen the language policy contested and undergo several iterations over the years. Whereas the 2002 SU Language Policy stated that Afrikaans was the default language of teaching and learning at the University (SU 2002), the essence of the 2016 Language Policy has shifted to "engagement with knowledge in a diverse society". This policy aims to "increase equitable access to SU for all students and staff, and to ensure that language practices facilitate pedagogically sound teaching and learning" (SU 2016:2). ${ }^{9}$

Language choice in consultant training is more complex because the training occurs in groups. At one point, we considered dividing the group into Afrikaans and English language streams. On reflection, we decided against this because we wanted the consultants to function as a team. We wanted them to be able to learn from one another and to create a shared space and community of practice. We requested feedback from the consultants about this. This was partly to help us to decide on the language(s) of instruction responsibly with input from the group

8 The 2002 SU Language Policy was accompanied by a detailed Language Plan that enabled academic environments to operationalise the Language Policy. The plan provided three options, Afrikaans, English or Afrikaans and English ('t-option'). This language policy has since 2002 undergone several iterations.

9 The 2016 SU Language Policy was approved in June 2016, and its implementation date was 1 January 2017 or as soon as possible thereafter. 
being taught and also to allow the group members to reflect on the language issue for their own development.

An earlier study that we conducted showed that while Afrikaans consultants viewed English as the lingua franca and were fluent in it, they had a need and an expectation to be able to use their first language academically (Daniels and Richards 2011). When we asked the consultants how they experienced English-medium training only, we received a range of answers:

That is no problem considering that some people could not speak Afrikaans. More Afrikaans would have been nice.

Ek het glad nie 'n probleem daarmee nie. Dit is baie belangrik dat almal geakkommodeer moet word. Ek is een van die bevoorregtes wat tweetalig is en gun dit aan die wat nie hierdie vaardigheid besit nie. [I don't have a problem with it at all. It's very important that everyone should be accommodated. I'm one of those privileged to be bilingual and grant [such accommodations to] those who don't possess this skill.]

It was a welcomed move, and interesting decision, especially knowing and seeing that Stellenbosch University seems to elevate Afrikaans more than other languages. It's like they say, Afrikaans first, then you can try others.

To provide a bit more linguistic balance and to act more in keeping with the SU Language Policy, we do, however, each mentor consultants in smaller groups and we have chosen to divide these linguistically into English and Afrikaans groups.

\section{Discussion}

These three transformative experiences show members of the Writing Lab community negotiating multilingualism and inclusivity in different rhetorical spaces. These types of experiences create an embodied understanding of these issues through which the participants are compelled to face not only those different from them but also themselves. They also must confront their perceptions on the notion of belonging. Who belongs to the University? To whom does the University belong? How does the Writing Lab fit into this?

Part of the writing centre paradox concerns the position of students:

Inasmuch as these writers are already students in the university (though, perhaps, only provisionally admitted), they are "citizens" of the university community and, therefore, protected by the rules of the democratic systems governing that community. However, as these writers write in ways the traditional system may not value, they are not yet full citizens.

(Carter 2009:144)

One challenge that we experience every time that we consult is that writing centres can be viewed as 'independent' spaces of learning catering to individuals' learning needs. This can decontextualise writers and their struggles and victories. It can silence certain narratives. It can overlook the need to keep language choice an active and ongoing process. Yet, the individual contact brings certain benefits. 
What the first two experiences foreground is that the Writing Lab can provide fertile ground for opportunities to develop a writing centre pedagogy that engages in a creative manner with "cultural conflicts" (Grimm 1996b:21), which are often invisible or ignored. By functioning as a type of contact zone (Pratt 1991), the writers and the consultants can

engage with suppressed aspects of history (including their own histories), ways to move into and out of rhetorics of authenticity; ground rules for communication across lines of difference and hierarchy that go beyond politeness but maintain mutual respect; a systematic approach to the all-important concept of cultural mediation.

(Pratt 1991:40)

In the first experience, the mode of communication, that is the one-to-one consultation, provided a safe space and flexibility of practice that allowed the student to shed his selfconsciousness about speaking in English and encouraged him rather to speak about his field of study. Leibowitz (2015:38) alludes to this view of "language in relation to individuals using language rather than to individuals as "language users"' as a way of responding to the language policy-in-education challenge. In our experience with Mandla, this type of engagement allowed him to develop agency and to practice his academic voice. His situation remains less than ideal because the University still does not create space for him to use his first language; however, in consultation he could carve out an academic space for himself. This in part addresses the concern raised by De Kadt and Mathonsi (2003:92) about the way in which some students are prevented from "participat[ing] fully ... and claim[ing] ownership of the knowledge construction required in tertiary education" by being cut off from their first language. Including Mandla in the consultant training provided the consultants with an opportunity to reflect on and confront their own beliefs and prejudices about multilingualism and inclusivity. It also established Mandla as an authority who could cocreate knowledge and take ownership of it.

What these two experiences further show is that for students from disadvantaged communities and educational backgrounds, barriers to and difficulties with access often occur at the point of entry. In the first case, it was a student in his first year of postgraduate studies and also his first year at a new university. In the second case, it was a first-year student making the transition from high school to university. These cases show how in the nonthreatening environment of the Writing Lab, individual ways of thinking about multilingualism and inclusivity can be deconstructed in a transformative way.

Emma, the consultant in the second experience, came to change her mind about the worthiness of the writer with whom she consulted. Her insights, however, came at a painful cost. She saw that the education system had let the student down and that this system was not necessarily an accurate gauge of a student's abilities. She felt powerless in the face of this realisation. As ideological as our positioning is, we are aware that lived experience is messy and complex. Students such as those in the first two experiences are still in a precarious position and are not able to bargain with the institution about adapting its conventions. The Writing Lab can provide various types of nonthreatening rhetorical spaces in which students can exercise their voices and negotiate their academic identities.

In the third experience, we realised early on that even with a measure of language equality in the Writing Lab's organisational structure (that is, two heads and roughly equal numbers of Afrikaans and English consultants), complete language equality between English and Afrikaans was not possible and that within certain contexts, accommodations had to be made. One reason 
was that many of our writers and consultants did not speak either language as a first language. We found that in order for these members to be able to participate in the activities of the Writing Lab and to be able to develop themselves, language equity took precedence over language equality.

The accommodations made by Afrikaans-speaking consultants to have their training in English allowed all the consultants to participate and interact in training in an "equitable and fulfilling way" (Leibowitz 2015:38). This response supported the findings of a previous research project conducted amongst a group of Afrikaans lecturers at the University. Although they identified with the Afrikaans language on a personal level, in their professional capacity, they opted to be inclusive and pragmatic (Richards and Daniels 2005).

Of course, this raises the question, What about the consultants who speak neither Afrikaans nor English as a first language? Although they can participate in all of the Lab's activities because we use English as a lingua franca, they are not treated equitably in our system because we do not use their first languages in training or mentoring.

We have found that when training new consultants or explaining to students or academic staff how we work, we tend to focus on the 'how' rather than on the 'why' of the pedagogy. This might be the influence of our pedagogy on us - we like people to make up their own minds through their own experience. We have also found that it is very different from what many students and lecturers are used to academically. The difference can be refreshing, but it can also be perplexing to some and hard to adapt to. Our challenge is "to maintain continual negotiation, protection and production" of the rhetorical spaces for which we are responsible (Nichols 2014:905).

For the Writing Lab, inclusion and fair use of language are more in line with our transformative agenda than is language equality. We have not come to this decision lightly but base it on research conducted in the Lab, reflections on our praxis, our experiences, many conversations with stakeholders and our observations of interactions in the various Lab spaces. As North (1984) and others such as Mahala (2007:4) have shown, writing centre work is "not fundamentally about 'fixing' this or that text, but about helping students develop a sense of agency as writers, helping them take charge of their own lives and educations" in increasingly impersonal and business-oriented universities that can drown out dissonant voices.

The type of inclusion to which we aspire is not letting 'others' into 'our' space but rather to construct and maintain the Writing Lab as a 'site of diversity':

A "site of diversity" cannot be one in which diversity is envisioned as something preexisting and given, and hence to be managed from above, but must rather involve giving those enacting diversity and seeking to diversify, the space to accept and reject and to construct themselves in ways which they desire.

(De Kadt and Mathonsi 2003:100)

We also aim to create a type of academic "mutualism" (Devet 2011:6) whereby all participants can benefit and develop by interacting and sharing knowledge and whereby all are valued. In this way, far from being colonisers, writing centres can "be liberatory" (Devet 2011:10) by showing how we are all connected through writing. More than that, we can "cultivate the writing center as fertile ground for the play of language" (Gillam 1991:10). This is a tactical 
move in creating agency for writing centres, as Mahala (2007) has demonstrated. We maintain that that agency extends to all in the writing centre, from the students to the staff. We do not wish to resolve the writing centre paradox.

\section{Conclusions}

We have been struck by how flexible we have had to be regarding language usage in the Lab in order to maintain our ethos of inclusivity so that we could truly describe our Lab as being for all students on campus. This has meant that we continually adapt our approach to language according to the situation. Doing this, however, has meant that we need to be critical about how we interact with people and to reflect on the extent to which we can describe our approach as equitable and inclusive. We are also confronted with the writing centre paradox daily.

We prefer to say that we help the writers to develop their writing and to find their academic voice rather than to say that we teach them how to write, but this does not make the value conflict disappear. For the writers to succeed at university, they are required to write a certain way, using a certain type of language, adhering to a certain type of format and so on. If they do not accomplish this, they do not succeed. One argument might be that academic language has developed to express precisely certain complex ideas; another might be that despite our claims to realign the power balance at university, we actually work to perpetuate it. A third option, our preference, is to see the at times conflictual relationship between student success within a system and students developing their own agency, voice and identity as a delicate balance rather than being able to achieve only one or the other.

Despite challenges such as those that emerged in the experiences discussed in this article, our writing lab is a place where "mutual transformations" as proposed by Grimm (1996b:17) occur - in the students with whom we consult and in the consultants who work with these students and in us as heads of the environment. The multilingualism that we engage in is of an inclusive nature, and while we function in the context of a language policy, we do not necessarily follow the policy to the letter. We see our practices and engagement with students as social and transformative; we experience time and again the duality and paradoxical nature of our identity - that of insider, embedded in the discipline, and also that of outsider, on the periphery. We see the benefits attached to both these roles and pedagogy where we work one-to-one with students. We have also come to realise that there are no simple, quick-fix answers to the complex matter of academic literacies development in a society such as South Africa. The ambiguities that we experience are beneficial, and we believe that they need not be resolved but rather should be embraced as they keep us engaged with our context and with the individual writers who visit the Writing Lab.

\section{References}

Alexander, N. 2004. The politics of language planning in post-apartheid South Africa. Language Problems and Language Planning 28(2): 113-130.

Archer, A. 2010. Challenges and potentials for writing centres in South African tertiary institutions. South African Journal of Higher Education 24(4): 495-510. 
Archer, A. and R. Richards. 2011. Introduction: Writing centres as alternate pedagogical spaces. In A. Archer and R. Richards (eds.) Changing spaces: Writing centres and access to higher education. Stellenbosch: SUN PReSS. pp. 5-15.

Badat, S. 2010. The challenges of transformation in higher education and training institutions in South Africa. Development Bank of Southern Africa.

Bailey, N. 2016. "The languages of other people": The experiences of tutors, administrators, and students in a South African multilingual writing center. Indiana State University, ProQuest Dissertations Publishing.

Boughey, C. 2010. Academic development for improved efficiency in the higher education and training system in South Africa. Development Bank of Southern Africa.

Boughey, C. and S. McKenna. 2016. Academic literacy and the decontextualised learner. CriSTaL 4(2): 1-9. doi:10.14426/cristal.v4i2.80

Carter, S. 2009. The writing center paradox: Talk about legitimacy and the problem of institutional change. College Composition and Communication 61(1): 133-152.

Cele, N. 2004. 'Equity of access' and 'equity of outcomes' challenged by language policy, politics and practice in South African higher education: The myth of language equality in education. South African Journal of Higher Education 18(1): 38-56.

Clarence, S. 2012. Making inter-disciplinary spaces for talk about and change in student writing and literacy development. Teaching in Higher Education 17(2): 127-137.

Clarence, S. and S. McKenna. 2017. Developing academic literacies through understanding the nature of disciplinary knowledge. London Review of Education 15(1): 38-49.

Contraband Cape Town. 2015. Luister. Available online:

https://www.youtube.com/watch?v=sF3rTBQTQk4 (Accessed 10 July 2017).

Daniels, S. and D. Daniels. 2017. How inclusive is the Writing Lab environment to students with disabilities? Reflections from one South African university. In R. Babcock and S. Daniels (eds.) Writing centers and disability. Southlake, TX: Fountainhead Press. pp. 305-328.

Daniels, S. and R. Richards. 2011. 'We're all in this thing together': An equitable and flexible approach to language diversity in the Stellenbosch University Writing Lab. In A. Archer and R. Richards (eds.) Changing spaces: Writing centres and access to higher education. Stellenbosch: SUN PReSS. pp. 33-44.

De Kadt, E. and N. Mathonsi. 2003. Writing in English with an 'African voice': Ownership, identity and learning. Journal for Language Teaching 37(1): 92-103.

Devet, B.D. 2011. Redefining the writing center with ecocomposition. Composition Forum 23: 1-16. Available online: http://compositionforum.com/issue/23/ (Accessed 30 May 2017).

Farren, P. 2016. 'Transformative pedagogy' in the context of language teaching: Being and becoming. World Journal on Educational Technology: Current Issues 8(3): 190-204.

Gee, J. 1990. Social linguistics and literacies: Ideology in discourse. London: Falmer Press.

Gillam, A. 1991. Writing center ecology: A Bakhtinian perspective. The Writing Center Journal 11(2): 3-11 
Gillespie, P. and N. Lerner. 2008. The Longman guide to peer tutoring. 2nd ed. New York: Pearson Longman Publishers.

Grimm, N. 1996a. Rearticulating the work of the writing center. College Composition and Communication 47(4): 523-548.

Grimm, N. 1996b. The regulatory role of the writing center: Coming to terms with a loss of innocence. The Writing Center Journal 17(1): 5-29.

Guttiérez, K. 2008. Developing a sociocritical literacy in the third space. Reading Research Quarterly 43(2): 148-164. doi:10.1598/RRQ.43.2.3

Harris, M. 1986. Teaching one-to-one: The writing conference. Urbana, Illinois: National Council of Teachers of English.

Language Centre. 2004. Writing Lab aims and services. Stellenbosch: Stellenbosch University.

Lea, M. and B. Street. 1998. Student writing and faculty feedback in higher education: An academic literacies approach. Studies in Higher Education 23(2): 157-172.

Leibowitz, B. 2015. The problems with language policy and planning. Journal of Language, Identity, and Education 14(1): 36-49.

Lillis, T. and M. Scott. 2007. Defining academic literacies research: Issues of epistemology, ideology and strategy. Journal of Applied Linguistics 4(1): 5-32.

Madiba, M. 2012. Multilingualism in class: A transformation strategy? Available online: http://www.mep.uct.ac.za/mep/news/2nov12 (Accessed 15 August 2017).

Mahala, D. 2007. Writing centers in the managed university. The Writing Center Journal 27(2): 3-17.

Nichols, P. 2014. Heeding the 'corpse in the cargo': The writing centre and the need to listen. South African Journal of Higher Education 28(3): 894-906.

North, S. 1984. The idea of a writing center. College English 46(5): 433-446.

Pratt, M. 1991. Arts of the contact zone. Profession 91: 33-40.

Richards, R. and S. Daniels. 2005. Speaking the same language? Afrikaans in teaching and learning at Stellenbosch University. Paper read at the South African Academic Development Association Conference, 28-29 November, Durban University of Technology, Durban, South Africa.

Ronesi, L. 2009. Theory in/to practice: Multilingual tutors supporting multilingual peers: A peer-tutor training course in the Arabian Gulf. The Writing Center Journal 29(2): 75-94.

RSA (Republic of South Africa). 2002. Language policy for higher education. Pretoria: Government Printers.

SU (Stellenbosch University). 2000. A strategic framework for the turn of the century and beyond. Available online: http://www.sun.ac.za/strategic_documents (Accessed 10 July 2017).

SU (Stellenbosch University). 2002. Language policy and language plan. Available online: http://www.sun.ac.za/Taal/Hersiening/docs/TaalbeleidHersien 16 Okt 2007 (2).pdf (Accessed 3 March 2010). 
SU (Stellenbosch University). 2016. Language policy of Stellenbosch University. Available online: http://www.sun.ac.za/english/Documents/Language/Final\%20June\%20Language\%20Policy\%20Nove mber\%202016.pdf (Accessed 16 August 2017).

Swart, E. and R. Pettipher. 2005. A framework for understanding inclusion. In E. Landsberg (ed.), D. Kruger and N. Nel (assistant eds.) Addressing barriers to learning: A South African perspective. Pretoria: Van Schaik Publishers. pp. 3-23.

Thesen, L. 2013. Risk in postgraduate writing: Voice, discourse and edgework. Critical Studies in Teaching and Learning (CriSTaL) 1(1): 103-122. doi:10.14426/cristal.v1i1.11 